\title{
The bioactivity of bacterium and fungi living associate with the sponge Reniera sp. against multidrug-resistant Staphylococcus aureus and Escherichia coli
}

\author{
AGUS TRIANTO ${ }^{1,4, \bullet}$, NIRWANI ${ }^{1}$, OKTORA SUSANTI $^{2}$, DIANSARI MAESAROH ${ }^{3}$, OCKY KARNA RADJASA $^{1,4}$ \\ ${ }^{1}$ Department of Marine Science, Faculty of Fisheries and Marine Science, Universitas Diponegoro. Jl. Prof. Dr. Soedharto, SH., Tembalang, Semarang \\ 50275, Central Java, Indonesia. Tel./fax. +62-24-7474698, •email: agustrianto.undip@gmail.com \\ Department of Fisheries and Marine, Universitas Lampung. Jl. Prof. Dr. Sumantri Brojonegoro No.1, Bandar Lampung, Lampung, Indonesia \\ ${ }^{3}$ Universitas Islam Negeri Sunan Ampel Surabaya. Jl. A. Yani 117 Surabaya Jl. Ahmad Yani No.117, Surabaya 60237, East Java, Indonesia \\ ${ }^{4}$ Central Laboratory for Research and Services, Universitas Diponegoro. Jl. Prof. Soedarto, SH, Tembalang, Semarang 50275, Central Java, Indonesia
}

Manuscript received: 20 May 2019. Revision accepted: 25 July 2019.

\begin{abstract}
Trianto A, Nirwani, Susanti O, Maesaroh D, Radjasa OK. 2019. The bioactivity of bacterium and fungi living associate with the sponge Reniera sp. against multidrug-resistant Staphylococcus aureus and Escherichia coli. Biodiversitas 20: 2302-2307. The study aimed to isolate and identify the sponge-associated microorganisms producing the antibacterial substances. The sponge Reniera sp. was collected by hand during skin diving in Karimunjawa Islands, Indonesia. The microbial symbionts were isolated with the dilution method and screened with the overlay method against the MDR S. aureus and E. coli. The bacterium was cultured in Zobell medium, while the fungi were cultured in malt extract broth (MEB) medium. The isolates were identified based on the molecular method. A total of 46 bacteria and 43 fungi were isolated, which 7 bacteria and 20 fungi exhibited antibacterial activity against the MDR E. coli and S. aureus strains. The molecular identification revealed that the active isolates close to Pseudoalteromonas maricaloris (99\%), Aspergillus nomius (96\%), Eurotium rubrum (99\%), and Penicillium sp. (100\%). Fractionation of K.J.16.U extract gave a fraction that active to the $S$. aureus and E. coli strains at concentration 150 and $15 \mu \mathrm{g}$ disk-1. The fraction K.J.16.U.1.4.4 exhibited stronger activity than that exhibited by chloramphenicol at $150 \mu \mathrm{g}$ disk-1. The sponge Reniera sp. collected from Karimunjawa Islands comprise bacterial and fungal isolates produced antibacterial compounds that inhibited the growth the MDR E. coli and S. aureus strains.
\end{abstract}

Keywords: Associate microorganisms, bioactive compounds, MDR pathogen, sponges Reniera

\section{INTRODUCTION}

The sponge is a primitive marine organism belongs to phylum Porifera that has important ecological roles as substrate stabilizer, bio-eroding, a shelter for small organisms, and in the cycle of silicon, carbon, nitrogen, and other nutrients (Bell 2008). As a sessile and filter feeder organism, the sponge is susceptible to physical damage, predatory attacks, and pathogenic infections. Sponge have developed the specific morphology, physiology, ability to produce diverse bioactive metabolites to support their survival. Some of the secondary metabolites possessed interesting bioactivities such as antibacterial (Salim et al. 2012), antifungal (Taylor et al. 2007), antiviral, antiinflammatory, antinociceptive (Souza et al. 2009), anticancer, and antioxidant (Trianto et al. 2011).

The Reniera sp. one of the sponges belongs to the Chalinidae family that well known as a rich source of the bioactive compounds, have attracted many researchers. Saito et al. (2004) isolated several bioactive compounds belong to reniera mycin, mimosamycin, and renierone that have bioactivity as antiproliferative against several cancer cells. Lunder et al. (2012) published the polymeric 3alkylpyridinum salts, isolated from the sponge Reniera sarai, a unique water-soluble compound that has a cardiotoxic effect. Urda et al. (2018) exhibited the bioactive compounds from Reniera sponge called Njoamines, a member of the alkaloid family contains a tricyclic nitrogenated core.

The surface or the inner parts of the sponges rich in nutrients than those present in seawater and sediments that suitable habitats for microorganisms. Some of these microorganisms are used as food while others live in symbiosis with the sponge as their host. Although the interaction between sponges and microorganisms is not yet clearly understood, there is an exchange of nutrients and secondary metabolites, which suggests that the survival of the sponge presumably depends on the positive hostsymbiont relationship. This kind of interaction may contribute to the nutrient acquisition and production of secondary metabolites in responsibility to protect the sponge body from microbial infection (Engel et al. 2002). Some of the bacteria living symbiotically with the sponge produce bioactive compounds (Kikuchi et al. 2018). Marine sponges are also rich in fungal symbionts that produce antibacterial and fungal compounds (Trianto et al. 2017a, b,). Marine microbes, both living freely and in association with the sponges, have been known to produce various bioactive compounds. The purpose of this work is to assess antibacterial the potential of bacteria and fungi isolated from sponge Reniera sp. collected from 
Karimunjawa Islands, Indonesia against two multi-resistant resistance bacteria (MDR).

\section{MATERIALS AND METHODS}

\section{Sponge collection and isolation of sponge microbial symbionts}

The sponge Reniera sp. was collected from Karimunjawa Islands, Jepara, Central Java, Indonesia, from the depth of 2-5 $\mathrm{m}$ by skin diving method. Each sponge specimen was put into a sterile zip-lock plastic bag and stored in a cool box until the isolation process. The specimens were washed with the sterile seawater prior to microbial isolation. The fungal isolates were isolated from the sponge by tapping method. A small part (ca.1 $\mathrm{cm} \mathrm{x} 1$ $\mathrm{cm} \times 0.3 \mathrm{~mm}$ ) of was cut from each specimen, and the sponge part was put onto the malt extract agar (MEA) media surface. While the microbial symbionts were isolated using the serial dilution method. The tissue solutions were spread on Zobell marine agar plates (Radjasa et al. 2007). Identification of the sponge was based on the in situ picture and spicule analysis (Hooper 2003; Kang et al. 2013).

\section{Screening for antibacterial activity}

Both of the bacterial and the fungal isolates were screened for the antibacterial activity against the pathogenic bacteria MRSA and MDR E. coli using the modified overlay method described by Anand et al. (2006). The bacterial symbionts were spotted on Zobell marine agar medium and incubated for three days, while the fungal strains were inoculated in the MEA medium and incubated for four days. The fresh culture of the pathogens was mixed with soft agar medium ( $1 \% \mathrm{v} / \mathrm{v})$ and overlaid over the agar surface of the previous microbial symbiont cultures. The plates were then incubated at $37^{\circ} \mathrm{C}$ for $24 \mathrm{~h}$. The antibacterial activity was defined by the presence of clear zones around the microbial symbiont.

\section{Gram test}

The bacterial Gram identification was carried out using the $\mathrm{KOH} \mathrm{3 \%}$ string and Gram staining tests. $\mathrm{KOH} \mathrm{3 \%}$ string test was done according to Ali et al. (2015); Dash and Payyappilli (2016), a loopful of the bacterial colony from the culture plate was emulsified over glass slide in the suspension of $3 \% \mathrm{KOH}$. Gram staining test was done according to Ayuningrum et al. (2017), using Gram's staining solution A (crystal violet), solution B (Lugol iodine), solution $\mathrm{C}$ (alcohol) and solution $\mathrm{D}$ (safranin).

\section{Mass culture and extraction of microbial symbionts}

The isolates with the strongest activity were chosen for further studies. The most active isolates, a bacterium, and three fungal isolates were cultured for the production of the bioactive compounds. The bacterial inoculum was prepared in 5-mL Zobell broth medium on a rotary shaker at room temperature, after $24 \mathrm{~h}$, the inoculum was serially transferred into larger volumes $(10,100$, and $1000 \mathrm{~mL})$. The fungi were cultured in malt extract broth (MEB) medium at room temperature for seven days (Radjasa \& Sabdono 2003). The microbial mass was separated from the culture medium for extraction of the bioactive substances. The bacterial culture was centrifuged at 1000 rpm for $10 \mathrm{~min}$, the supernatant was discarded, and the pellet was soaked in $\mathrm{MeOH}$ for $24 \mathrm{~h}$. The fungal mycelia were separated from the culture medium by filtration with a paper filter; then the mycelia were soaked in $\mathrm{MeOH}$ for 24 $\mathrm{h}$. The solution was filtered and concentrated with the rotary evaporator in vacuo to obtain the crude extracts. The extracts were partitioned using a solvent mixture of ethyl acetate and $\mathrm{H}_{2} \mathrm{O}$ solvents to provide the organic and water fractions.

\section{Antibacterial test of the extract}

The antibacterial test was conducted by the disk diffusion method. The extracts were dissolved in ethyl acetate to prepare the stock solutions with the concentration $1.5 \mu \mathrm{g} \mu \mathrm{L}-1$, then $10 \mu \mathrm{L}$ of the stock solutions was impregnated into a sterile paper disk with diameter $5 \mathrm{~mm}$ in to give the final concentration at $15 \mu \mathrm{g}$ disk-1. The paper disks were placed on the nutrient agar medium surface that was previously inoculated with the pathogenic bacteria. The standard antibiotic (chloramphenicol, $15 \mu \mathrm{g}$ disk-1) was used in this test. The antibacterial activity was defined based on the inhibition zones around the paper disk (Ozdemir et al. 2006).

\section{Molecular identification}

The DNA extraction was carried out using the Chelex method (Walsh et al. 1991). Selected colonies were inoculated in $50-100 \mu \mathrm{L} \mathrm{ddH} 2 \mathrm{O}$ and $1 \mathrm{~mL}$ of $0.5 \%$ saponin in phosphate buffer solution (PBS) $1 \times$ (stored overnight). The mixture was centrifuged at $12000 \mathrm{rpm}$ for $10 \mathrm{~min}$ (1 $\mathrm{rpm}=1 / 60 \mathrm{~Hz}$ ), and then the supernatant was discarded. Then, $100 \mu \mathrm{L}$ ddH2O and $50 \mu \mathrm{L}$ of $20 \%$ Chelex 100 were added to the final solution, and the solution was boiled for $10 \mathrm{~min}$ and vortexed once for $5 \mathrm{~min}$. The mixture was centrifuged at $12000 \mathrm{rpm}$ for $10 \mathrm{~min}$ and stored at $-20^{\circ} \mathrm{C}$.

The bacterial DNA that was used for 16S rRNA gene sequencing was amplified by polymerase chain reaction (PCR) using the universal primers $27 \mathrm{~F}$ (5'AGAGTTTGATCMTGGCTCAG-3') and 1492R (5'TACGGTTAACCTTG TTACGACTT-3'). The fungal DNA that was used for 5.8S rDNA gene sequencing was amplified by PCR with the internal transcribed spacer (ITS) region ITS 1 (5'TCCGTAGGTGAA CCTGCGG-3') and the primer ITS4 (5'TCCTCCGCTTATTGATATGC-3').

The DNA sequencing was conducted at Macrogen Laboratory, Korea. The results of DNA sequences were preliminarily aligned with ClustalW Multiple Sequence Alignment. Phylogenetic analysis was performed using MEGA 6. The phylogenetic trees were determined by the neighbor-joining method using Kimura's two-parameter model. 


\section{RESULTS AND DISCUSSION}

\section{Isolation the microbial and screening for antibacterial activity of the isolates}

A total of 46 bacteria and 43 fungi were isolated from the sponge Reniera sp. Among the isolates, 5 bacteria inhibited $S$. aureus and $E$. coli, and 3 of the active isolates inhibited both pathogenic bacteria. Whilst, 19 and 7 fungal isolates inhibited $S$. aureus and $E$. coli, respectively. Among the active fungal isolates, 6 of them inhibited both bacteria (Figure 1). The preliminary test revealed that $23.6 \%$ of the strains were capable of inhibiting the MDR pathogens MRSA and E. coli. The antibacterial test of the isolates extract showed one bacterium along with three fungal isolates having strong activity against the antagonist bacteria.

The Reniera sponge is known to have symbiotic microbes either bacteria or fungi. Sponge Reniera sp. collected from Panjang Island, Jepara Central Java contains five associated bacteria that one of the bacteria is Chromohalobacter salexigens strain DSM 3043 active against $P$. aeruginosa, E. cloaceae, A. baumannii, and $S$. aureus (Asagabaldan 2017). The microbial community plays important roles in sponge survival and adaptation to environmental change. The microorganisms serve the food supply of the sponge both internal exchange and with the environment (Kiran et al. 2018). Bacteria also produced bioactive compounds that protect the sponge from biofouling organisms (Aguila-Ramírez et al. 2014; Satheesh et al. 2016).

\section{Bioactivity of bacterial biomass and fungal mycelia extract}

The most active isolates were cultured in higher mass to provide the extract for further study. The extraction of the bacterial biomass and fungal mycelia yielded methanolic extract with concentrations of 5.3-18.7\%. The methanol extraction yielded crude extract that was partitioned with $\mathrm{H}_{2} \mathrm{O}$ and ethyl acetate before conducting the antibacterial assay. The antibacterial screening results are shown in Table 1.

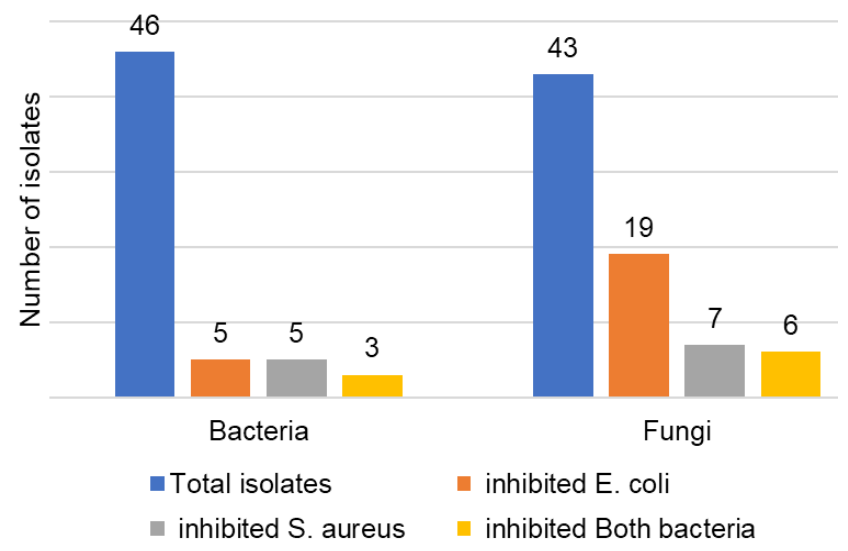

Figure 1. The number of total and active bacterial and fungal isolates of the sponge Reniera sp.

Table 1. Bioactivity of ethyl acetate extract of the bacterial biomass and fungal mycelia obtained from 1liter batch culture

\begin{tabular}{lccccc}
\hline Isolat & $\begin{array}{c}\text { Bacterial/ Mycelial } \\
\text { weight }(\mathbf{g})\end{array}$ & $\begin{array}{c}\text { Extract weight } \\
(\mathbf{m g})\end{array}$ & $\begin{array}{c}\text { Extract concentration } \\
(\boldsymbol{\%})\end{array}$ & \multicolumn{2}{c}{$\begin{array}{c}\text { The diameter of the inhibition zone } \\
(\mathbf{m m})\end{array}$} \\
\cline { 4 - 6 } & 6.6 & 348.4 & 5.3 & $\boldsymbol{E}$ coli & MRSA \\
\hline SKSBT.0.3.29 & 17.9 & 3340.0 & 18.7 & 10.3 & 7.2 \\
SKSJT. J. 16 H & 31.0 & 3280.0 & 10.6 & 10.7 & 10.6 \\
SKSJT. J. 16 U & 9.4 & 1300.0 & 13.8 & 7.4 & 2.6 \\
SKSJT. J.19 & &
\end{tabular}

Note: The diameter of the inhibition zone of (+) control chloramphenicol: 14.83 and $13.95 \mathrm{~mm}$ against E. coli and $S$. aureus, respectively. (-) control ethyl acetate and $\mathrm{H}_{2} \mathrm{O}$ fraction did not show activity $(0.00 \mathrm{~mm})$.

Table 3. Identification of fungal strains isolated from Reniera sp. Samples were based on BLAST analysis of the internal transcribed spacer (ITS) region

\begin{tabular}{lcllc}
\hline \multicolumn{1}{c}{ Strain } & $\begin{array}{c}\text { Sequence } \\
\text { length }(\mathbf{n t})\end{array}$ & \multicolumn{1}{c}{ Related cultivated strain (BLAST) } & Acc. no & Similarity (\%) \\
\hline SKSBT.0.3.29 & 1165 & Pseudoalteromonas maricaloris strain KMM636 & NR 025009.1 & $99 \%$ \\
K.J.16.U & 1062 & Aspergillus nomius strain SGE19 & JN709035.1 & $96 \%$ \\
K.J.16.H & 545 & Eurotium rubrum strain SGE27 & JX232274.1 & $99 \%$ \\
K.J.19 & 983 & Penicillium sp. DY115-21-10-M23 & KF411603.1 & $100 \%$ \\
\hline
\end{tabular}




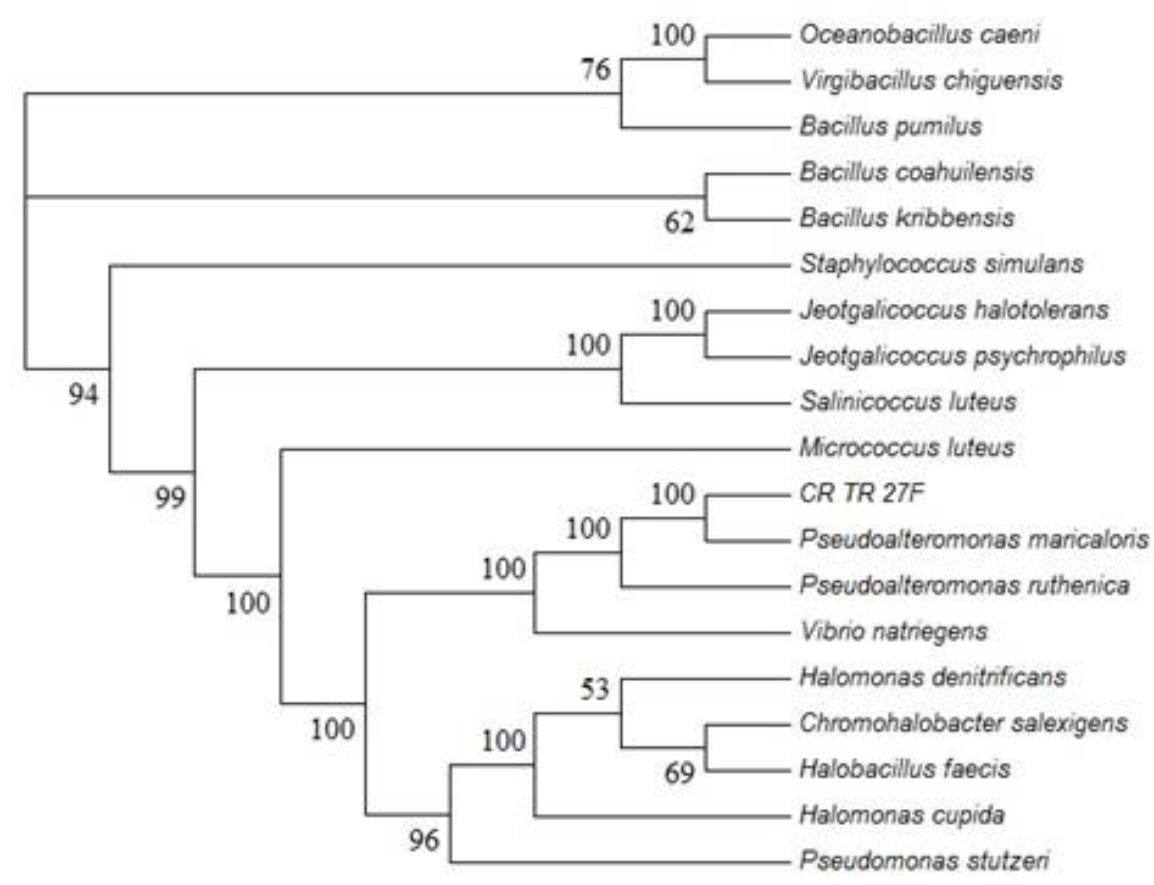

Figure 2. Phylogenetic tree of bacterial isolate

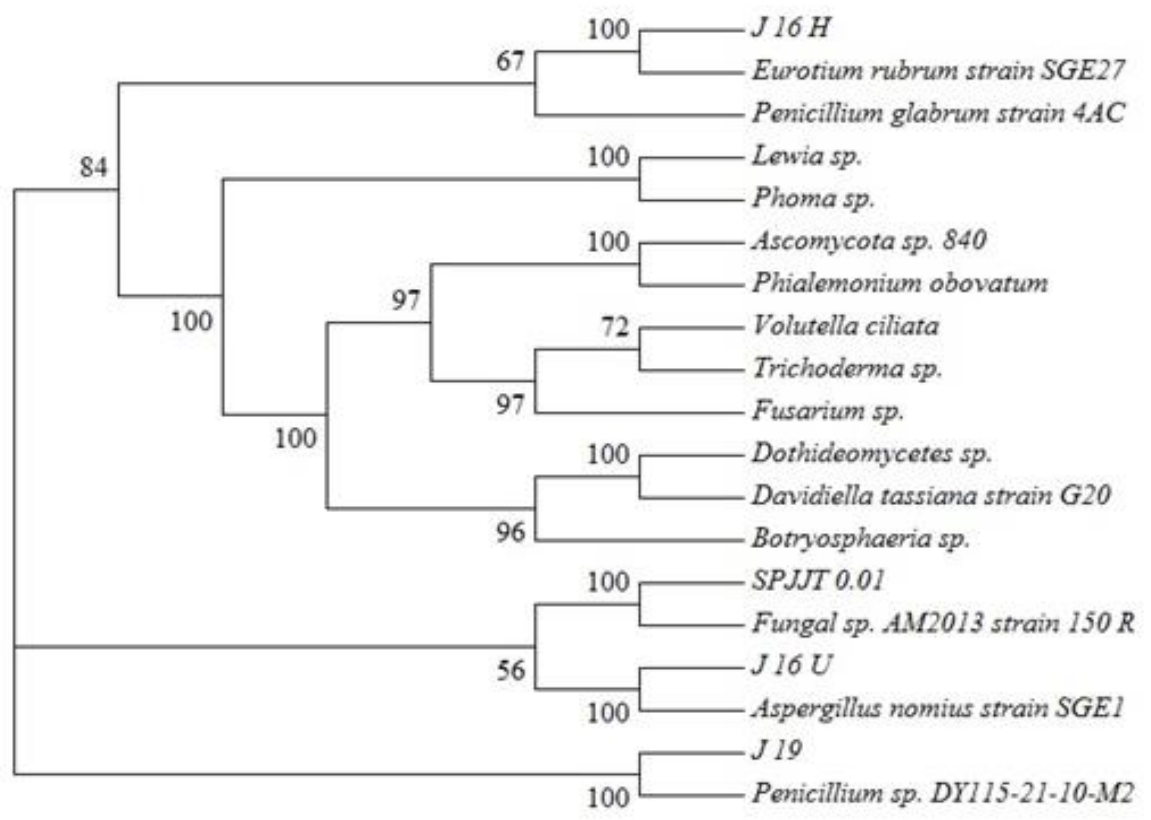

Figure 3. Phylogenetic tree of fungal isolates

Marine bacteria and fungi are well known as potential sources of natural products. For example, Pseudoalteromonas sp. reported producing compound pentabromopseudilin, a promising anti-MRSA and myosin ATPase inhibition with activities at a level comparable to those of commercial drugs (Kum et al. 2017). Other researches showed that Pseudoalteromonas sp. living associated with sponge Halisarca ectofibrosa produce compounds that inhibit the growth of Bacillus subtilis and Vibrio anguillarum (Rungprom et al. 2008; Schinke et al. 2017). A review paper by Xu et al (2015) describes broadly the potential of marine fungi as sources bioactive compounds. The review showed there are 105 marine fungal strains used for the isolation of antibacterial or 
antifungal compounds. Mangrove and sponges are the most riches sources of fungi, while Aspergillus and Penicillium are the most common fungi in the marine ecosystem. Other review depicted the high potential of marine fungi especially the genus Aspergillus of antibacterial and anticancer (Bladt et al. 2013).

\section{Identification of the isolates}

The ethyl acetate fraction of K.J.16.U was selected Molecular identification of the active bacterial and fungal symbionts based on 16S rRNA and 5.8S rDNA revealed that the active strains SKSBT.0.3.29, K.J.16.U, K.J.16.H, and K.J.19 were closely related to Pseudoalteromonas maricaloris, Aspergillus nomius, Eurotium rubrum, and Penicillium sp., respectively for bioassay-guided fractionation because of its high antibacterial activity, which yielded six fractions (K.J.16.U.1.4.1-6) (Table 2). The results obtained from BLAST homology of the bacterial and fungal symbionts of Reniera sp. are described by phylogenetic trees (Figures 2 and 3 ).

The molecular-based identification indicated that the active isolate is Pseudoalteromonas maricaloris with the BLAST homology $99 \%$ similarity. While the fungal isolates identified as Aspergillus nomius strain SGE19, Eurotium rubrum strain SGE27, and Penicillium sp. DY115-21-10-M23 with BLAST homology 99\% similarity $96 \%$, 99\%, and 100\% similarity, respectively (Table 2). Genus Pseudoalteromonas are heterotrophic bacteria include are essential components of the marine environment and have diverse habitats including coastal and open water areas, bottom sediments, and living associated with marine plants and animals. P. maricaloris has been isolated from a sponge, Fascaplysinopsis reticulata, collected from Australia. It has also been reported having antibacterial activity against $S$. aureus, $E$. coli, Proteus vulgaris, Enterococcus faecium, and Bacillus subtilis and also cytotoxic activity against tumor cells (Ivanova et al. 2002; Radjasa et al. 2007). Pseudoalteromonas also produces extracellular antibacterial compounds that inhibit the Vibrio parahaemolyticus causing acute hepatopancreatic necrosis disease (Wang et al. 2018). Asagabaldan et al. (2017) isolated bacterial strains from the sponge belonging to the genus Haliclona (Reneira) that were active against Pseudomonas aeruginosa, Staphylococcus aureus, Acinetobacter baumannii, and Enterobacter cloacae.

Penicillium sp., Aspergillus sp., and Eurotium sp. have been isolated from the sponge Tethya aurantium collected from the Istrian Peninsula, Croatia, which possesses the secondary metabolite mycotoxin that exhibited antineoplastic properties. A. nomius is reported as an insect parasite and a producer aflatoxin B1, B2, G1, and G2, mycotoxins, that toxic to humans, animals, and insects (Calderari et al. 2013; Afonso et al. 2017). However, A. nomius has also known as lipase producer that potentially used for the production of fatty acid methyl ester in the biodiesel industry (Rakchai et al. 2016). Eurotium rubrum commonly found in grain products, poultry feed, bakery products, dried fruits, spices, soil, hypersaline waters, and Dead Sea soil (Butinar et al. 2005). These Eurotium reported to producing diketopiperazine compounds that potential in the cosmetic industry by inhibited melanogenesis (Kamauchi et al. 2016). The E. rubrum has also reported producing a metabolite called flavoglaucin, auroglaucin, isotetrahydorauroglaucin, eoechinulins $\mathrm{A}$ and $\mathrm{B}$, echinulin, preechinulin, nechinulin E, epiheveadride, and questin. The compounds have activities as anticancer, antioxidant, antibacterial, cytoprotection against peroxynitrite, hepatotoxic (Slack et al. 2009). Penicillium sp. is well-known for its ability to produce secondary metabolites with diverse biological effects. Penicillium sp. has been reported contains Peniopyranone, a bioactive compound inhibits acetylcholinesterase, that potential for neurodegenerative diseases such as Alzheimer's dementia and Parkinson's disease (Li et al. 2017). Penicillium sp. also well-known as a source of prenylated indole alkaloids having interesting biological activities such as antitumor, anthelmintic, calmodulin inhibitory, and antibacterial (Yang et al. 2018).

To conclude, the sponge Reniera sp. collected from Karimunjawa Islands comprise bacterial and fungal isolates produced antibacterial compounds that inhibited the growth the MDR E. coli and $S$. aureus strains. The fungus $A$. nomius has potential as a source of antibacterial compounds that having stronger activity against MRSA and $E$. coli.

\section{ACKNOWLEDGMENTS}

This research was partially supported by The Ministry of Research, Technology, and Higher Education through Post Graduate Scheme. We thank USAID for supporting this research through PEER grant.

\section{REFERENCES}

Afonso E, Raquel C, Valadares L, Peporine N, Santos F, Tallarico M. 2017. Aflatoxins produced by Aspergillus nomius ASR3, a pathogen isolated from the leaf-cutter ant Attasexdens rubropilosa. Rev Brasileira Farmacog 27: 529-532.

Aguila-Ramírez RN, Hernández-Guerrero CJ, González-Acosta B, IdDaoud G, Hewitt S, Pope J. 2014. Antifouling activity of symbiotic bacteria from sponge Aplysina gerardogreeni. Intl Biodeterior Biodegrad 90: 64-70.

Ali F, Bahadar S, Rahman KU, Khan I. Zeb A, Khan J, Daud M, Hassan A, Rabbani NK, Khattak AA, Jadoon FK, Hayat. 2015. Isolation and identification of lipase producing bacteria from coal mines of Darra Adam Khel, Kyber Pakhtoonkhwa, Pakistan. Int J Biosci 7 (2): 187 191.

Anand TP, Bhat AW, Shouche YS, Roy U, Siddharth J, Sarma SP. 2006. Antimicrobial activity of marine bacteria associated with sponges from the waters off the coast of southeast India. Microbiol Res 16: 252-262.

Asagabaldan MA, Ayuningrum D, Kristiana R, Sabdono A, Radjasa OK, Trianto A. 2017. Identification and antibacterial activity of bacteria isolated from marine sponge Haliclona (Reniera) sp. against multidrug resistant human pathogen. IOP Conf Ser: Earth Environ Sci. 55: 012019. DOI: 10.1088/1755-1315/55/1/012019

Ayuningrum D, Kristiana R, Asagabaldan MA, Sabdono A, Radjasa OK, Nuryadi H, Trianto A. 2016. Isolation, characterisation and antagonistic activity of bacteria symbionts hard coral Pavona sp. isolated from Panjang Island, Jepara against infectious Multi-drug Resistant (MDR) bacteria. IOP Conf Ser: Earth Environ Sci. 55: 012019. DOI: 10.1088/1755-1315/55/1/012029 
Bell JJ. 2008. The functional roles of marine sponges. Estuar Coast Shelf Sci 79 (3): 341-353.

Bladt TT, Frisvad JC, Knudsen PB, Thomas Ostenfeld Larsen. 2013 Anticancer and antifungal compounds from Aspergillus, Penicillium, and other filamentous fungi. Molecules 18: 11338-11376.

Butinar L, Zalar P, Frisvad JC, Gunde-Cimerman N, 2005. The genus Eurotium members of indigenous fungal community in hypersaline waters of salterns. FEMS Microbiol Ecol 51: 155-166

Calderari TO, Iamanaka BT, Frisvad JC, Pitt JI, Sartori D, Luiz J. 2013. The biodiversity of Aspergillus section Flavi in brazil nuts: From rainforest to consumer. Intl J Food Microbiol 160: 267-272.

Dash C, Payyappilli RJ. 2016. KOH string and Vancomycin susceptibility test as an alternative method to Gram staining. J Intl Med Dent 3 (2): 88-90.

Engel S, Jensen PR, Fenical W. 2002. Chemical ecology of marine microbial defense. J Chem Ecol 28: 1971-1985.

Hooper JNA. 2003. Sponguide: Guide to sponge collection and identification, version 2003. Queensland Museum, Australia

Ivanova EP, Shevchenko LS, Sawabe T, Lysenko AM, Svetashev VI, Gorshkova NM, Satomi M, Christen R, Mikhailov VV. 2002. Pseudoalteromonas maricaloris sp. nov. isolated from an Australian sponge and reclassification of Pseudoalteromonas aurantia NCIMB 2033 as Pseudoalteromonas flavipulchra sp. nov. Intl J Syst Evol Microbiol 52: 32-71.

Kamauchi H, Kinoshita K, Sugita T, Koyama K. 2016. Conditional changes enhanced production of bioactive metabolites of marinederived fungus Eurotium rubrum. Bioorg Med Chem Lett 26: 4911 4914.

Kang DW, Kyung JL, Chung JS. 2013. Two new marine sponges of the genus Haliclona (Haplosclerida: Chalinidae) from Korea. Anim Syst Evol Divers 29: 51-55.

Kikuchi S, Okada K, Cho Y, Yoshida S, Kwon E, Yotsu-Yamashita M. 2018. Isolation and structure determination of lysiformine from bacteria associated with marine sponge Halichondria okadai. Tetrahedron 74 (27): 3742-3747.

Kiran GS, Sekar S, Ramasamy P, Thinesh T, Hassan S, Lipton AN. 2017. Marine sponge microbial association: Towards disclosing unique symbiotic interactions. Mar Environ Res 140: 169-179

Kum D-Y, Nazari M, McPhail KL, Cooper CS, Suyama TL. 2017. Twostep total synthesis of an anti-MRSA and myosin-inhibiting marine natural product pentabromopseudilin via Suzuki-Miyaura coupling of a MIDA boronate ester. Tetrahedron Lett 58: 3374-3376.

Li XS, Tan MH, Lu MM, Liu CX, Guo ZY, Zhang L. 2017. New $\gamma$ pyranone and nucleoside derivatives from Penicillium sp. Phytoch Lett 20: $285-288$.

Lunder M, Drevenšek G, Hawlina S, Sepčić K, Žiberna L. 2012. Cardiovascular effects induced by polymeric 3-alkylpyridinium salts from the marine sponge Reniera sarai. Toxicon 60 (6): 1041-1048.

Ozdemir G, Karabay NU, Dalay MC, Pazarbasi B. 2006. Antimicrobial activities of the volatile component and various extracts of Dictyopteris membranacea and Cystoseira barbata from the coast of Izmir, Turkey. Pharm Biol 44: 183-188.

Radjasa OK, Sabdono A. 2003. Screening of secondary metaboliteproducing bacteria associated with corals using $16 \mathrm{~S}$ rDNA-based approach. J Coast Develop 7: 11-19.

Radjasa OK, Salasia SIO, Sabdono A, Weise J, Imhoff JF, Lammler C, Risk MJ. 2007. Antibacterial activity of marine bacterium Pseudomonas sp. associated with soft coral Sinularia polydactyla against Streptococcus equi subsp. zooepidemicus. Intl J Pharmacol 3: 170-174.

Rakchai N, Kittikun A, Zimmermann W. 2016. The production of immobilized whole-cell lipase from Aspergillus nomius ST57 and the enhancement of the synthesis of fatty acid methyl esters using a twostep reaction. J Mol Catal B Enzym 133: 10-13.

Rungprom W, Siwu ERO, Lambert LK, Dechsakulwatana C, Barden MC, Kokpol U, Blanchfield JT, Kita M, Garson MJ. 2008. Cyclic tetrapeptides from marine bacteria associated with the seaweed Diginea sp. and the sponge Halisarca ectofibrosa. Tetrahedron 64: 3147-3152

Saito N, Tanaka C, Koizumi YI, Suwanborirux K, Amnuoypol S, Pummangura S. 2004. Chemistry of Reniera mycins. Part 6: Transformation of Reniera mycin $\mathrm{M}$ into jorumycin and Reniera mycin $\mathrm{J}$ including oxidative degradation products, mimosamycin, renierone, and renierol acetate. Tetrahedron 60 (17): 3873-3881.

Salim AA, Khalil ZG, Capon RJ. 2012. Structural and stereochemical investigations into bromotyrosine-derived metabolites from southern Australian marine sponges Pseudoceratina spp. Tetrahedron 6: 98029807.

Satheesh S, Ba-akdah MA, Al-Sofyani AA. 2016. Natural antifouling compound production by microbes associated with marine macroorganisms - A review. Electron J Biotechnol 21: 26-35.

Schinke C, Martins T, Queiroz SCN, Melo IS, Reyes FGR. 2017. Antibacterial compounds from marine bacteria, 2010-2015. J Nat Prod 80: 1215-1228.

Slack GJ, Puniani E, Frisvad JC, Samson RA, Miller JD, Peterson SW. 2009. Secondary metabolites from Eurotium species, Aspergillus calidoustus, and $A$. insuetus common in Canadian homes with a review of their chemistry and biological activities. 113: 480-490.

Souza ET, de Lira DP, de Queiroz AC, da Silva DJC, de Aquino AB. 2009. The antinociceptive and anti-inflammatory activities of caulerpin, a bisindole alkaloid isolated from seaweeds of the genus Caulerpa. Mar Drugs. 7: 689-704

Taylor MW, Radax R, Steger D, Wagner M. 2007. Sponge-associated microorganisms: Evolution, ecology, and biotechnological potential. Microbiol Mol Biol Rev 71: 295-347.

Trianto A, Hermawan I, de Voogd NJ, Tanaka J. 2011. Halioxepine, a new meroditerpene from an Indonesian sponge Haliclona sp. Chem Pharm Bul 59: 1311-1313.

Trianto A, Radjasa OK, Pribadi R, Widyaningsih S, Wittriansyah K, Yusidharta I, Wiratno, Riniatsih I. 2017a. Isolation and identification of sponge-associated fungus producing anti-multidrug-resistant (MDR) bacterial substances. Res J Pharm Biol Chem Sci 8: 63

Trianto A, Sabdono A, Rochaddi B, Triningsih D W. 2017b. Exploration of marine sponges-associated fungi producing antifungal compounds. Asian J Microbiol Biotech Environ Sci 19: 588-593.

Urda C, Pérez M, Rodríguez J, Fernández R, Jiménez C, Cuevas C. 2018. Njaoamine I, a cytotoxic polycyclic alkaloid from the Haplosclerida sponge Haliclona (Reniera) sp. Tetrahedron Lett 59 (26): 2577-1580.

Walsh PS, Metzger DA, Higuchi R. 1991. Biotechniques 30th Anniversary gem: Chelex 100 as a medium for simple extraction of DNA for PCR-based typing from forensic material. Biotechniques 10: 506-513.

Wang H, Wang C, Tang Y, Sun B, Huang J, Song X. 2018. Pseudoalteromonas probiotics as potential biocontrol agents improve the survival of Penaeus vannamei challenged with acute hepatopancreatic necrosis disease (AHPND)-causing Vibrio parahaemolyticus. Aquaculture 494: 30-36.

Xu L, Meng W, Cao C, Wang J, Shan W, Wang Q. 2015. Antibacterial and antifungal compounds from marine fungi. Mar Drugs 13: 34793513.

Yang B, Tao H, Lin X, Wang J, Liao S, Dong J. 2018. Prenylated indole alkaloids and chromone derivatives from the fungus Penicillium sp. SCSIO041218. Tetrahedron 74 (1): 77-82. 